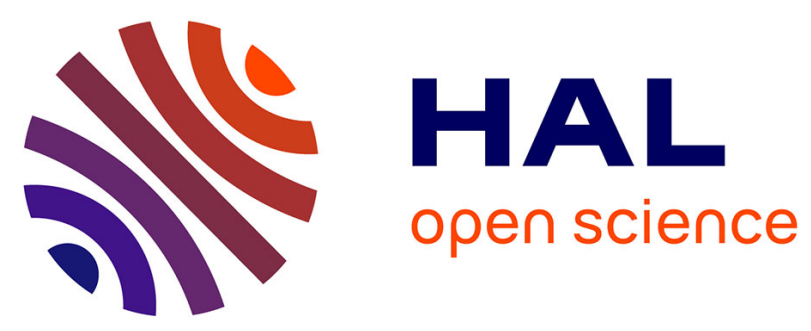

\title{
Does diagnosis of the metabolic syndrome detect further men at high risk of cardiovascular death beyond those identified by a conventional cardiovascular risk score? The DECODE Study.
}

The Decode Study Group

\section{To cite this version:}

The Decode Study Group. Does diagnosis of the metabolic syndrome detect further men at high risk of cardiovascular death beyond those identified by a conventional cardiovascular risk score? The DECODE Study.: Metabolic syndrome and cardiovascular risk scores. European Journal of Cardiovascular Prevention and Rehabilitation, 2007, 14 (2), pp.192-9. 10.1097/01.hjr.0000230107.78524.da . inserm-00125978

\section{HAL Id: inserm-00125978 https://www.hal.inserm.fr/inserm-00125978}

Submitted on 23 Jan 2007

HAL is a multi-disciplinary open access archive for the deposit and dissemination of scientific research documents, whether they are published or not. The documents may come from teaching and research institutions in France or abroad, or from public or private research centers.
L'archive ouverte pluridisciplinaire HAL, est destinée au dépôt et à la diffusion de documents scientifiques de niveau recherche, publiés ou non, émanant des établissements d'enseignement et de recherche français ou étrangers, des laboratoires publics ou privés. 


\section{Does diagnosis of the metabolic syndrome detect further men at high risk of cardiovascular death beyond those identified by a conventional cardiovascular risk score? The DECODE Study}

\section{The DECODE Study Group}

Short title: Metabolic syndrome and cardiovascular risk scores

Abstract: 226 words

Text: 3011 words

38 references

4 Tables

1 Figure

Correspondence to:

Beverley Balkau

INSERM U780-IFR69

16 Avenue Paul Vaillant Couturier

94807 Villejuif cedex

Telephone: 0033145595161

Fax: 0033147269454

e-mail: balkau@vjf.inserm.fr 
Abstract

Background It is not known whether the metabolic syndrome detects further individuals at high risk of cardiovascular (CVD) mortality, beyond those identified by a conventional cardiovascular risk score.

Design A prospective study

Methods 2790 non-diabetic men, aged 50-69 years from seven population-based European cohorts participating in the DECODE Study, were followed for CVD mortality over 10 years. Results $51 \%$ of the men had an estimated 10-year risk of fatal CVD under $5 \%$, using the European SCORE project equation, and $22 \%$ of them had the metabolic syndrome, as defined by the National Cholesterol Education Program Adult Treatment Panel III. In the low risk men, the hazards ratio for fatal CVD, after adjusting for age and study centre, was $2.71(1.33-5.51)$ for men with the syndrome $(p<0.01)$ compared to men without the syndrome. A large waist circumference $(>102 \mathrm{~cm})$ carried an odds ratio of $2.24(1.05-4.76)$ in the low CVD risk men

Conclusions Men with a low cardiovascular risk score and the metabolic syndrome had a significantly higher risk of fatal CVD than those without the syndrome. Use of the metabolic syndrome in clinical practice is thus justified in men, but the waist circumference provided a simpler diagnostic tool with similar fatal CVD risk in these low risk men. A large waist circumference could be used for pre-screening, and could be included in CVD risk scores.

Key words: cardiovascular diseases, epidemiology, obesity, risk factors 


\section{Introduction}

Identification of the metabolic or insulin resistance syndrome is currently being recommended to identify people at risk for cardiovascular disease (CVD), and for diabetes [1-5]. Numerous studies have shown that both prevalent and incident diabetes and CVD are associated with the syndrome, as defined by the World Health Organization (WHO)[1], by the European Group for the study of Insulin Resistance (EGIR)[6], by the National Cholesterol Education Program, Adult Treatment Panel III (NCEP-ATP III)[2] or by adaptations of these definitions [7-24]. Further, in 2005 two additional definitions of the metabolic syndrome have been published, one by the International Diabetes Federation (IDF)[25], and a second, a revised version of the NECP-ATP III definition, by the American Heart Association/National Heart, Lung, and Blood Institute (AHA/NHLBI) [26].

However, while the syndrome may predict diabetes, this is mainly due to those subjects with the syndrome who have high glucose concentrations (impaired glucose tolerance or impaired fasting glucose) at baseline $[9,11,18,19,21,22]$. A combination of other diabetes risk factors (glucose and insulin at both fasting and 2 hours post load, triglycerides, HDL-cholesterol, systolic and diastolic blood pressure, weight, height) has been shown to better predict diabetes than either the WHO or the NCEP-ATP III defined syndromes [16,19]. For cardiovascular mortality, there are many studies [7-17,22-24], and the syndrome is significantly predictive, even after adjusting for the traditional CVD risk factors (blood pressure, cholesterol, smoking as well as age) $[10,11,13,15,17,23,24]$. However, the Framingham Risk equation appears to have a better predictive value than the metabolic syndrome [16].

If the syndrome is to be a useful concept in clinical practice it should identify individuals at risk of CVD beyond those who can already be identified by a cardiovascular risk score. The European SCORE project risk equation [27] is appropriate for identifying those at low and high risk of fatal CVD (10-year risk under and over 5\%) in European populations [28]. 
In the DECODE cohort, we study whether the syndrome identified individuals who died within 10 years of CVD among those a) at low CVD risk, b) at high CVD risk. Further we study in these two groups the predictive value of the syndrome abnormalities taken singly and as a combination of the two clinical variables, waist circumference and arterial blood pressure, and of the hypertriglyceridaemic waist, which has been proposed as a simple tool for the diagnosis of the syndrome [29].

\section{Methods}

\section{Study population}

The methods used to recruit cohorts into the DECODE Study have been reported in previous publications [14,30-32]. Briefly, coordinators of studies with data on mortality from populationbased studies or large studies on occupational groups in Europe, and with measured glucose concentrations at fasting and 2 hours after a 75g OGTT, were contacted and invited to participate. Data were collated and analyzed in the Diabetes and Genetic Epidemiology Unit of the National Public Health Institute in Helsinki, Finland.

We analyze data from seven population-based studies from the DECODE study cohorts, 2790 men aged 50 to 69 years with measures of fasting glucose, triglycerides, HDL-cholesterol concentrations, waist circumference and systolic and diastolic blood pressures. There were too few cardiovascular events in this DECODE population with the syndrome variables to permit analysis outside this age range. Women were included in the DECODE cohort, but the number of CVD deaths was small, and so results have not been included in this report. Diabetic men, both known and screened (fasting plasma glucose $\geq 7.0 \mathrm{mmol} / \mathrm{l}$ ) were excluded [1]. All glucose concentrations were transformed to plasma glucose concentrations, as already documented in other DECODE Study publications [14,30-32]. 
Each study had ethical approval in accord with local requirements.

\section{Score Risk Equation for CVD risk stratification}

The probability of 10-year CVD mortality was calculated for all men in the study, using the formulae developed by the European SCORE project, summing the probabilities of CHD and CVDnon-CHD deaths [27]. This score includes sex, age, smoking status, total cholesterol and systolic blood pressure. These risk equations do not take into account diabetes or glucose concentrations, nor obesity measures. The coefficients for 'low risk countries' were used for Spain, Italy, the Netherlands, and 'high risk countries' for Finland, Sweden, Poland and the UK. Men with a 10-year cardiovascular mortality risk under 5\% were identified as being at 'low risk' and men with a risk over 5\% as 'high risk', in line with the European guidelines [27].

\section{The metabolic syndrome}

The NCEP-ATP III defined metabolic was used, modified to include treatment for hypertension [2]. This definition requires the presence of at least three of the following five abnormalities: hyperglycaemia: fasting plasma glucose $\geq 6.1 \mathrm{mmol} / 1$; high arterial blood pressure: systolic $\geq 130 \mathrm{mmHg}$ and/or diastolic $\geq 85 \mathrm{mmHg}$ or treatment for hypertension; hypertriglyceridaemia: triglycerides $\geq 1.7 \mathrm{mmol} / \mathrm{l} ;$ hypo-HDL cholesterolaemia: HDL-cholesterol $<1.04 \mathrm{mmol} / \mathrm{l}$; central adiposity: waist circumference $>102 \mathrm{~cm}$.

\section{Vital status}

Vital status was followed for the men who attended the baseline examination. Those who emigrated, for whom vital status could not be confirmed, were censored at the time of emigration. Follow-up was almost complete. Fatal events were classified using the International Classification of Diseases: CVD was defined by codes 401-448 of the Eighth or Ninth Revisions and codes I10- 
I79 for the Tenth Revision $[33,34]$. Causes of death were either classified by an independent panel, or death certificates were used.

\section{Statistical Analyses}

SPSS for Windows 11.0 has been used for all statistical analyses.

Men were divided into four groups according to $<5 \% / \geq 5 \%$ estimated CVD risk and absence/presence of the NCEP-ATP III metabolic syndrome. The mean values of risk factors and the ranges over the studies, are presented (Table 1).

The Cox proportional hazards model was used to estimate the 10-year hazards ratios for fatal CVD, using men without the syndrome and at low CVD risk, as the reference group. The 10-year CVD cumulative hazards curves were calculated for these four risk groups. Because the syndrome and the CVD risk score include the same variables (arterial blood pressures), and age is included in the SCORE risk equation, models were build successively, with initially no adjustment, and then successive adjustment for centre, for centre and age and finally for centre, age and the estimated CVD risk from the SCORE equation [27]. The final adjustment for the estimated CVD risk aimed to examine whether the residual risk in the men with the syndrome was due to the traditional CVD risk factors or to other factors included in the syndrome, such as abdominal obesity, hyperglycemia and the specific lipid abnormalities.

In order to examine the CVD mortality linked with the syndrome in the high CVD risk group, the hazards ratios were also determined separately, in the groups with low and high CVD risk scores.

To determine which of the syndrome abnormalities was driving the CVD risk, hazards ratios for the individual syndrome abnormalities were estimated, within the two CVD risk groups, with the 
abnormalities defined according to the NCEP-ATP III thresholds. Finally, the risk associated with the combination of the two clinically determined variables, large waist circumference and high arterial blood pressure was evaluated, and also the risk associated with the combination of high triglycerides and large waist circumference [29].

\section{Results}

The characteristics of the men, aged 50 to 69 years, included in this study are shown (Table 1). The follow-up in this analysis was limited to ten years. The most frequent abnormality contributing to the metabolic syndrome was high arterial blood pressure, with a frequency of $72 \%$ and the syndrome was present in $24 \%$ of the men.

The SCORE CVD risk equation identified $51 \%$ of the men $(n=1416)$ as having a risk of fatal CVD under $5 \%$ over the next 10 years (Table 2$)$. Of these, $22 \%(n=306)$ had the metabolic syndrome.

Overall $4.2 \%(n=118)$ of the men died of CVD, $2.2 \%(33 / 1416)$ of those at low CVD risk and $6.2 \%$ (85/1374) of those at high CVD risk. In both the low and the high CVD risk groups, the mean values of all variables indicated a higher risk in those with the metabolic syndrome (Table 2). This was particularly true for the syndrome variables.

The primary objective of this analysis was to determine, in men at low CVD risk, whether those with the metabolic syndrome had significantly higher CVD mortality than those without the syndrome. The hazards ratios changed little after adjustment, and even after adjusting for the estimated CVD risk, the metabolic syndrome remained predictive with a hazards ratio (95\% confidence interval) of $2.42(1.20-4.88)(\mathrm{p}<0.05)$ (Table 3). For the high CVD risk men, the hazards ratios were more affected by the adjustments: when adjusted for centre alone, the risks of fatal CVD were higher than for the low CVD risk men with the syndrome, but after adjustment for 
age and centre, the hazards ratios were similar to the men with low CVD risk and the syndrome. Further, adjusting for the estimated 10-year CVD risk using the SCORE equation, the observed hazards ratio in the high risk men was greatly reduced, showing that the risk was due to high values of the classical CVD risk factors. Analyzing the two CVD risk groups separately, showed that the metabolic syndrome did not predict CVD mortality in the high risk men, with hazards ratios very close to one.

The cumulative hazards for the four groups of men are shown in Figure 1, and illustrate the similar risks in men at high CVD risk, with and without the syndrome and in men at low CVD risk with the syndrome.

Among the individual syndrome abnormalities, for the men in the low CVD risk group, large waist, high blood pressure, low HDL-cholesterol were predictive of fatal CVD with similar hazards ratios of $2.24(1.05-4.76), 2.67(1.21-5.88)$ and $2.72(1.35-5.45)$ respectively (Table 4). The highest hazards ratio was associated with the combination of large waist and high arterial blood pressure, 3.54 (1.65-7.59). These men were $13 \%$ of those at low CVD risk, a smaller target group for potential intervention than the $22 \%$ with the metabolic syndrome in this group.

The individual metabolic syndrome variables were not predictive of 10 year CVD mortality in the high CVD risk men. 


\section{Discussion}

In men with a low risk of fatal CVD, as estimated by the SCORE project risk equations [27], presence of the metabolic syndrome at baseline increased the chances of fatal CVD over the 10-year follow-up, using the clinical definition of the metabolic syndrome given by the NCEP-ATP III [2]. This risk was related to syndrome abnormalities and not to the risk identified by the SCORE equation for CVD mortality, as the syndrome remained predictive after adjustment by the estimated CVD risk. The positive predictive values for fatal CVD in men using the waist circumference alone was $4.1 \%$ and for the metabolic syndrome $4.2 \%$, with hazards ratios of 2.24 and 2.71 respectively; the waist criteria provides a simpler alternative to the syndrome as screening could be targeted towards a smaller fraction of the population, $17 \%$ versus $22 \%$ of the men at low CVD risk. The high blood pressure, large waist criteria had an associated hazards ratio of 3.54, a positive predictive value of $5.3 \%$ and screened $13 \%$ of the low risk population: these two variables are readily available in general practice.

\section{Limitations of the Study}

Our study is limited by the small number of cardiovascular deaths. In contrast to other studies, we have limited the analysis to subjects between 50 and 69 years, as there were too few men with an estimated risk of fatal CVD deaths over 5\% before 50 years of age and too few subjects over 69 years, thus there has been no extrapolation of the results to other age groups, based on few deaths in these age groups. Unfortunately we do not have access to cardiovascular morbidity in most of these DECODE populations. The CVD risk score developed for Europe is appropriate, but scores such as the Framingham risk equation should provide similar results, and would rank subjects similarly, although many of these score are for morbidity and not mortality. Of the men identified by the SCORE risk equation as being at high fatal CVD risk, $6.1 \%$ died of CVD, in contrast to the expected $5 \%$. However, the SCORE equation is not country specific, and only stratifies according 
to 'high' and 'low' risk countries. The data were also analyzed deleting the 44 men who were diabetic according to the 2-hour post-load glucose criteria. The hazards ratios were little altered.

A further limitation is the use of the NCEP-ATP III criteria for the definition of the metabolic syndrome, which we have already discussed [35]. This definition was designed for clinical use, and our study was designed to provide practical answers. It was a consensus definition from an expert committee in the United States, where the blood pressure levels are lower than in Europe [36] and the waist circumferences are larger [35]. Using the thresholds of the NCEP-ATP III syndrome, we classified two thirds of our population as having high arterial blood pressure. In almost all populations, the waist circumference criteria of the NCEP-ATP III screen more women than men. These thresholds were not chosen on the basis of CVD mortality, and given the higher rate of CVD in men, waist circumference thresholds which screen more men than women would seem appropriate. With better adapted thresholds, the waist circumference might provide a very convenient first screening tool, without the need for taking a blood sample. The syndrome criteria are not optimal, and indeed it would be preferable to have a continuous metabolic score rather than a dichotomous classification [37].

We have chosen to study only the NCEP-ATP III syndrome [2], so that these results can be compared with other publications, most of which use this syndrome definition. This study is only of mortality as morbidity data were not available in all of the populations in this study. Further the follow-up is limited to 10 years. The metabolic syndrome may be a risk factor for a higher lifetime risk of cardiovascular consequences, and studying only mortality and for only 10 years, may limit findings on the utility of the metabolic syndrome. Altough Type 2 diabetes has been identified as a CVD risk equivalent to established CVD [2], we have studied only one outcome of the metabolic syndrome in these analyses, fatal CVD and not progression to diabetes, which in the long term would have CVD consequences, although not necessarily yet within a 10-year period. [38]. Using a 
combined endpoint, diabetes and CVD events may have an important impact on the risk associated with the syndrome. Information on incident diabetes is not available in these populations. It should be noted, that these results are for European Caucasians aged 50 to 69 years, thus similar analyses are required in other populations and age groups to determine whether they can be generalized.

\section{Other Studies}

A previous analysis of the DECODE cohort [14] examined the risk associated with the metabolic syndrome, using adaptations of the WHO syndrome definition, and using various combinations of the abnormalities. Indeed, all syndrome definitions used were predictive of CVD mortality in men, in accord with our results.

One published study analyzed major CVD events, stratifying subjects on the 10-year CVD risk (fatal and non-fatal events) estimated from the Framingham score, with high risk being a $>20 \%$ probability of an event [13]. Participants were from the placebo groups of two clinical trials (4S and AFCAPS/TexCAPS) on cholesterol lowering in high risk individuals, average age 58 years, and more than $75 \%$ were men. In men at low CVD risk, those with the syndrome had a higher cumulative incidence of a major coronary event than those without the syndrome, but this was not formally tested. In these two clinical trials, the metabolic syndrome conferred statistically significant age-adjusted hazards ratios of 1.5 and 1.4 for a major coronary event. In our study, the corresponding fatal CVD hazards ratio for the syndrome was higher in men at low CVD risk, being 2.7 .

Data from the population based San Antonio Study [16] show that while the metabolic syndrome had an odds ratio of almost 4 for CVD events, after adjustment by the Framingham CVD risk score, this risk was reduced to non-significant $1.14(0.76-1.71)$. These data were not analyzed by sex, and could well be compatible with our results, where the metabolic syndrome was only found to be 
predictive in the low risk men. ROC curves show that the Framingham risk score has higher sensitivity/specificity for CVD events than the metabolic syndrome, but this is not surprising given that the Framingham score has been specifically developed to include variables that best predict CVD events, in contrast to the metabolic syndrome which is a combination of potential risk factors, published by an expert committee.

In the ARIC cohort, more than 1000 incident events in men and women 45 to 64 years, over a follow-up of 11 years, were registered [17]. The metabolic syndrome was found to be predictive of CVD events, both in men and women, but as in the San Antonio Study, the metabolic syndrome did not improve the coronary risk prediction beyond the level achieved by the Framingham risk score.

The Hoorn Study, a European cohort of middle aged men and women, adjusting for the Framingham category reduced the hazards ratio of fatal and non-fatal CVD events associated with the metabolic syndrome, to $1.64(1.11-2.44)$ in men and $1.17(0.73-1.87)$ in women [23].

Analyses need to be repeated in other studies with more subjects and so more CVD deaths and with an extended age range. The sensitivity of the results to the actual thresholds used in the metabolic syndrome definition should also be studied.

\section{Conclusions}

Our study has shown that the metabolic syndrome, as defined by NCEP-ATP III, is predictive of fatal cardiovascular disease, but only in the men with a low risk of fatal CVD. The syndrome provides no further predictive information in men at high CVD risk. Of note is the predictive value of the waist circumference with similar odds ratios to the NCEP-ATP III syndrome in the low risk men. It is a simple screening tool and it could be included as a risk factor in CVD risk scores. 


\section{Acknowledgements}

We would like to thank Tony Fitzgerald for discussions on the analyses with the European SCORE equation.

\section{Conflict of Interest}

This analysis has been carried out with the help of grants from Novartis Pharma AG, Basel Switzerland, Sweden; from Paulo Foundation and from Future Forum Research Grant 2004. The DECODE Study was initially funded by Novo Nordisk, Bagsvaerd, Denmark, Novo Nordisk Foundation 2005.

\section{Organization}

The DECODE Study (Diabetes Epidemiology: Collaborative analysis Of Diagnostic Criteria in Europe) was undertaken in 1997 upon the initiative of the European Diabetes Epidemiology Group.

\section{Studies and investigators in this collaborative study are:}

Finland, FINMONICA: J. Tuomilehto ${ }^{1,2,3}$, P. Jousilahti ${ }^{2}$, J. Lindström ${ }^{1,2}$, ${ }^{1}$ Department of Public Health, University of Helsinki, Helsinki; ${ }^{2}$ Department of Epidemiology and Health Promotion, National Public Health Institute, Helsinki; ${ }^{3}$ South Ostrobothnia Central Hospital, Seinäjoki.

Italy, Cremona Study: M.P. Garancini, G. Calori, G. Ruotolo, Clinical Cardiovascular Biology Research Centre, San Raffaele Scientifc Institute, Milan.

The Netherlands, The Hoorn Study: L.M. Bouter ${ }^{1}$, J.M. Dekker ${ }^{1}$, R.J. Heine ${ }^{1}$, G. Nijpels ${ }^{1}$, C.D.A. Stehouwer ${ }^{1,2}$. ${ }^{1}$ Institute for Research in Extramural Medicine, Vrije Universiteit Medical Center, Amsterdam. ${ }^{2}$ Dept of Medicine, University Hospital Maastricht, AZ Maastricht.

Poland, POLMONICA (Krakow): A. Pajak, E Kawalec. Department of Clinical Epidemiology and Population Studies, Institute of Public Health, Unit of Health Care, Collegium Medicum, Jagellonian University, Krakow.

Sweden, Northern Sweden MONICA: M. Eliasson and B. Stegmayr. Department of Public Health and Clinical Medicine, Umeå University, Umeå.

United Kingdom, Isle of Ely Diabetes Project: N.J. Wareham, MRC Epidemiology Unit, Strangeways Research Labs, Cambridge.

United Kingdom, Newcastle Heart Project: N. Unwin, N. Ahmad, K.G.M.M. Alberti, L. Hayes, Department of Medicine and Epidemiology and Public Health, University of Newcastle, Newcastle.

\section{Secretariat:}

K. Borch-Johnsen, Steno Diabetes Center, Gentofte, Denmark;

Q. Qiao, J. Tuomilehto, Department of Epidemiology and Health Promotion, National Public Health Institute, Helsinki; Department of Public Health, University of Helsinki, Helsinki.

\section{Data analysis:}

Q. Qiao, Department of Public Health, University of Helsinki; Diabetes and Genetic Epidemiology Unit, Department of Epidemiology and Health Promotion, National Public Health Institute, Helsinki, Finland;

B. Balkau, INSERM U780-IFR69, Villejuif, France.

\section{Writing Committee:}

B. Balkau, INSERM U780-IFR69, Villejuif, France.

Q. Qiao, J Tuomilehto, Department of Public Health, University of Helsinki; Diabetes and Genetic Epidemiology Unit, Department of Epidemiology and Health Promotion, National Public Health Institute, Helsinki, Finland; South Ostrobothnia Central Hospital, Seinäjoki, Finland (JT)

K Borch-Johnsen, Steno Diabetes Center, Gentofte, Denmark;

K Pyörälä, Department of Medicine, University of Kuopio, Finland. 


\section{References}

1 World Health Organization Consultation. Definition, diagnosis and classification of diabetes mellitus and its complications Part 1: Diagnosis and classification of diabetes mellitus. Report of a WHO Consultation. Geneva, Switzerland 1999.

2 Expert Panel on Detection, Evaluation, and Treatment of High Blood Cholesterol in Adults. Executive Summary of The Third Report of The National Cholesterol Education Program (NCEP) Expert Panel on Detection, Evaluation, and Treatment of High Blood Cholesterol in Adults (Adult Treatment Panel III). JAMA 2001; 285:2486-2497.

3 National Cholesterol Education Program (NCEP) Expert Panel on Detection, Evaluation, and Treatment of High Blood Cholesterol in Adults (Adult Treatment Panel III). Third Report of the National Cholesterol Education Program (NCEP) Expert Panel on Detection, Evaluation, and Treatment of High Blood Cholesterol in Adults (Adult Treatment Panel III) final report. Circulation 2002: 106:3143-3421.

4 Proceedings of the American College of Endocrinology Insulin Resistance Syndrome Conference. Washington, DC, USA. August 25-26, 2002. Endocr Pract 2003; 9(Suppl 2):236252.

5 Grundy SM, Brewer HB Jr, Cleeman JI, Smith SC Jr, Lenfant C; American Heart Association; National Heart, Lung, and Blood Institute. Definition of metabolic syndrome: Report of the National Heart, Lung, and Blood Institute/American Heart Association conference on scientific issues related to definition. Circulation 2004; 109:433-438.

6 Balkau B, Charles MA. Comment on the provisional report from the WHO consultation. European Group for the Study of Insulin Resistance (EGIR). Diabet Med 1999; 16:442-443.

7 Isomaa B, Almgren P, Tuomi T, Forsen B, Lahti K, Nissen M, Taskinen MR, Groop L. Cardiovascular morbidity and mortality associated with the metabolic syndrome. Diabetes Care 2001; 24:683-689.

8 Lakka HM, Laaksonen DE, Lakka TA, Niskanen LK, Kumpusalo E, Tuomilehto J, Salonen JT. The metabolic syndrome and total and cardiovascular disease mortality in middle-aged men. JAMA 2002; 288:2709-2716.

9 Klein BE, Klein R, Lee KE. Components of the metabolic syndrome and risk of cardiovascular disease and diabetes in Beaver Dam. Diabetes Care 2002; 25:1790-1794.

10 Resnick HE, Jones K, Ruotolo G, Jain AK, Henderson J, Lu W, Howard BV; Strong Heart Study. Insulin resistance, the metabolic syndrome, and risk of incident cardiovascular disease in nondiabetic american indians: the Strong Heart Study. Diabetes Care 2003; 26:861-867.

11 Sattar N, Gaw A, Scherbakova O, Ford I, O'Reilly DS, Haffner SM, Isles C, Macfarlane PW, Packard CJ, Cobbe SM, Shepherd J. Metabolic syndrome with and without C-reactive protein as 
a predictor of coronary heart disease and diabetes in the West of Scotland Coronary Prevention Study. Circulation 2003; 108:414-419.

12 Hunt KJ, Resendez RG, Williams K, Haffner SM, Stern MP; San Antonio Heart Study. National Cholesterol Education Program versus World Health Organization metabolic syndrome in relation to all-cause and cardiovascular mortality in the San Antonio Heart Study. Circulation 2004; 110:1251-1257.

13 Girman CJ, Rhodes T, Mercuri M, Pyorala K, Kjekshus J, Pedersen TR, Beere PA, Gotto AM, Clearfield M; 4S Group and the AFCAPS/TexCAPS Research Group. The metabolic syndrome and risk of major coronary events in the Scandinavian Simvastatin Survival Study (4S) and the Air Force/Texas Coronary Atherosclerosis Prevention Study (AFCAPS/TexCAPS). Am $J$ Cardiol 2004; 93:136-141.

14 Hu G, Qiao Q, Tuomilehto J, Balkau B, Borch-Johnsen K, Pyorala K; DECODE Study Group. Prevalence of the metabolic syndrome and its relation to all-cause and cardiovascular mortality in non-diabetic European men and women. Arch Intern Med 2004; 164:1066-1076.

15 Malik S, Wong ND, Franklin SS, Kamath TV, L'Italien GJ, Pio JR, Williams GR. Impact of the metabolic syndrome on mortality from coronary heart disease, cardiovascular disease, and all causes in United States adults. Circulation 2004; 110:1245-1250.

16 Stern MP, Williams K, Gonzalez-Villalpando C, Hunt KJ, Haffner SM. Does the metabolic syndrome improve identification of individuals at risk of type 2 diabetes and/or cardiovascular disease? Diabetes Care 2004; 27:2676-2681.

17 McNeill AM, Rosamond WD, Girman CJ, Golden SH, Schmidt MI, East HE, Ballantyne CM, Heiss G. The metabolic syndrome and 11-year risk of incident cardiovascular disease in the Atherosclerosis Risk in Communities study. Diabetes Care 2005; 28:385-390.

18 Mykkanen L, Kuusisto J, Pyorala K, Laakso M. Cardiovascular disease risk factors as predictors of type 2 (non-insulin-dependent) diabetes mellitus in elderly subjects. Diabetologia 1993; 36:553-559.

19 Hanson RL, Imperatore G, Bennett PH, Knowler WC. Components of the "metabolic syndrome" and incidence of type 2 diabetes. Diabetes 2002; 51:3120-3127.

20 Laaksonen DE, Lakka HM, Niskanen LK, Kaplan GA, Salonen JT, Lakka TA. Metabolic syndrome and development of diabetes mellitus: application and validation of recently suggested definitions of the metabolic syndrome in a prospective cohort study. Am J Epidemiol 2002; 156:1070-1077.

21 Lorenzo C, Okoloise M, Williams K, Stern MP, Haffner SM; San Antonio Heart Study. The metabolic syndrome as predictor of type 2 diabetes: the San Antonio heart study. Diabetes Care 2003; 26:3153-3159. 
22 Ford ES. Risks for all-cause mortality, cardiovascular disease, and diabetes associated with the metabolic syndrome. A summary of the evidence. Diabetes Care 2005; 28:1769-1778.

23 Dekker JM, Girman C, Rhodes T, Nijpels G, Stehouwer CDA, Bouter LM, Heine RJ. Metabolic syndrome and 10-year cardiovascular disease risk in the Hoorn Study. Circulation 2005; 112:666-673.

24 Sundstrom J, Riserus U, Byberg L, Zethelius B, Lithell H, Lind L. Clinical value of the metabolic syndrome for long term prediction of total and cardiovascular mortality: prospective, population based cohort study. BMJ 2006; 332:878-82.

25 Alberti KGMM, Zimmet P, Shaw J, IDF Epidemiology Task Force Consensus Group. The metabolic syndrome-a new worldwide definition. Lancet 2005; 24:1059-1062

26 Grundy SM, Cleeman JI, Daniels SR, Donato KA, Eckel RH, Franklin BA, Gordon DJ, Krauss RM, Savage PJ, Smith SC Jr, Spertus JA, Costa F; American Heart Association; National Heart, Lung, and Blood Institute. Diagnosis and management of the metabolic syndrome: an American Heart Association/National Heart, Lung, and Blood Institute Scientific Statement. Circulation 2005; 112:2735-2752.

27 Conroy RM, Pyörälä K, Fitzgerald AP et al. and the SCORE project group (2003) Estimation of ten-year risk of fatal cardiovascular disease in Europe: the SCORE project. Eur Heart J 2003; 24:987-1003.

28 Third joint task force of European and other societies on cardiovascular disease prevention in clinical practice (constituted by representatives of eight societies and by invited experts).European guidelines on cardiovascular disease prevention in clinical practice. Eur $J$ Cardiovasc Prev Rehabil 2003; 10:S1-S10.

29 Lemieux I, Pascot A, Couillard C, Lamarche B, Tchernof A, Almeras N, Bergeron J, Gaudet D, Tremblay G, Prud'homme D, Nadeau A, Despres JP. Hypertriglyceridemic waist: A marker of the atherogenic metabolic triad (hyperinsulinemia; hyperapolipoprotein B; small, dense LDL) in men? Circulation 2000; 102:179-184.

30 The DECODE Study Group on behalf of the European Diabetes Epidemiology Group (1999) Glucose tolerance and mortality: comparison of WHO and American Diabetes Association diagnostic criteria. Lancet 1999; 354:617-621.

31 The DECODE Study Group. Is the current definition for diabetes relevant to mortality risk from all causes and cardiovascular and noncardiovascular diseases? Diabetes Care 2003; 26:688-696.

32 DECODE Study Group. Gender difference in all-cause and cardiovascular mortality related to hyperglycaemia and newly-diagnosed diabetes. Diabetologia 2003; 46:608-661.

33 International Classification of Diseases, Injuries and Causes of Death. Revision 9. Geneva, World Health Organization, 1997. 
34 International Classification of Diseases, Injuries and Causes of Death. Revision 10. Geneva, World Health Organization, 1993.

35 Balkau B, Vernay M, Mhamdi L, Novak M, Arondel D, Vol S, Tichet J, Eschwege E, D.E.S.I.R. Study Group. The incidence and persistence of the NCEP (National Cholesterol Education Program) metabolic syndrome. The French D.E.S.I.R. study. Diabetes Meta. 2003; 29:526-532.

36 Wolf-Maier K, Cooper RS, Banegas JR, Giampaoli S, Hense H-W, Joffres M, Kastarinen M, Poulter N, Primatesta P, Rodriguez-Artalejo F, Stegmayr B, Thamm M, Tuomilehto J, Vanuzzo D, Vescio F. Hypertension Prevalence and Blood Pressure Levels in 6 European Countries, Canada, and the United States. JAMA 2003; 289:2362-2369.

37 Hillier TA, Rousseau A, Lange C, Lepinay P, Cailleau M, Novak M, Calliez E, Ducimetiere P, Balkau B. Practical way to assess metabolic syndrome using a continuous score obtained from principal components analysis: The D.E.S.I.R. Cohort. Diabetologia 2006 (in press)

38 Qiao Q, Jousilahti P, Eriksson J, Tuomilehto J. Predictive properties of impaired glucose tolerance for cardiovascular risk are not explained by the development of overt diabetes during follow-up. Diabetes Care 2003; 26:2910-2914. 


\section{Legend to Figure:}

Cumulative hazards of 10 year cardiovascular mortality in non-diabetic men aged 50 to 69 years, stratified according to the estimated cardiovascular risk from the SCORE project equation (10 year fatal risk of CVD $</ \geq 5 \%$ ) and absence/presence of the NCEP-ATP III metabolic syndrome.

Note: the curves for the two groups of men with a high CVD risk score, with and without the syndrome, are superimposed, and that the scale for the hazards for women and men differ. The DECODE Study. 
Table 1 Characteristics (numbers, \% and means (SD)) of 2790 non-diabetic men aged 50 to 69 years, according to sex. The DECODE Study.

\begin{tabular}{|c|c|c|}
\hline & $\begin{array}{l}\text { Mean or } \\
\text { percentage }\end{array}$ & $\begin{array}{l}\text { Range } \\
\text { across centres }\end{array}$ \\
\hline Maximum follow-up (years) & 10.0 & $\begin{array}{l}6.9-10 \\
(10 \text { years in } 73 \% \text { of the men) }\end{array}$ \\
\hline Age (years) & $50-69$ & $50-64$ to $50-69$ \\
\hline Smoking & $32 \%$ & $18 \%-43 \%$ \\
\hline Waist (cm) & 95 & $92-98$ \\
\hline Waist > $102 \mathrm{~cm}$ & $20 \%$ & $13 \%-31 \%$ \\
\hline Fasting plasma glucose $(\mathrm{mmol} / \mathrm{l})$ & 5.53 & $5.23-5.85$ \\
\hline $\begin{array}{l}\text { Impaired fasting glucose } \\
\text { (fasting plasma glucose } \\
6.1-6.9 \mathrm{mmol} / \mathrm{l} \text { ) }\end{array}$ & $19 \%$ & $10 \%-38 \%$ \\
\hline & 1.65 & $1.42-1.82$ \\
\hline \multicolumn{3}{|l|}{ Triglyceride (mmol/l) } \\
\hline Triglyceride $\geq 1.70 \mathrm{mmol} / 1$ & $37 \%$ & $27 \%-43 \%$ \\
\hline Total cholesterol (mmol/1) & 6.20 & $5.52-6.59$ \\
\hline HDL cholesterol (mmol/1) & 1.25 & $1.18-1.40$ \\
\hline HDL cholesterol $<1.04 \mathrm{mmol} / \mathrm{l})$ & $28 \%$ & $11 \%-35 \%$ \\
\hline Systolic Blood Pressure (mmHg) & 139 & $133-148$ \\
\hline $\begin{array}{l}\mathrm{SBP} / \mathrm{DBP} \geq 130 / 85 \mathrm{mmHg} \\
\quad \text { or treated for hypertension }\end{array}$ & $72 \%$ & $61 \%-87 \%$ \\
\hline NCEP-ATP III syndrome & $26 \%$ & $16 \%-37 \%$ \\
\hline
\end{tabular}



Table 2 Characteristics (mean (SD)) of the non-diabetic men aged 50-69 years, according to the estimated cardiovascular risk from the SCORE project equation and absence/presence of the NCEP-ATP III metabolic syndrome. The DECODE Study.

\begin{tabular}{|c|c|c|c|c|}
\hline & \multicolumn{4}{|c|}{$\begin{array}{l}\text { CVD risk over } 10 \text { years from the SCORE project equation } \\
<5 \% \\
<5 \%\end{array}$} \\
\hline & $\begin{array}{c}\text { no } \\
\text { syndrome }\end{array}$ & syndrome & no syndrome & syndrome \\
\hline & $\begin{array}{l}20 \text { deaths, } \\
1110 \text { men }\end{array}$ & $\begin{array}{l}13 \text { deaths, } \\
306 \text { men }\end{array}$ & $\begin{array}{l}57 \text { deaths, } \\
941 \text { men }\end{array}$ & $\begin{array}{l}28 \text { deaths, } \\
433 \text { men }\end{array}$ \\
\hline Age (years) & $56(5)$ & $56(4)$ & $62(5)$ & $61(5)$ \\
\hline Waist $(\mathrm{cm})$ & $92(8)$ & $102(9)$ & $93(8)$ & $103(9)$ \\
\hline BMI $\left(\mathrm{kg} / \mathrm{m}^{2}\right)$ & $25.6(2.8)$ & $29.0(3.6)$ & $25.8(3.0)$ & $29.1(3.5)$ \\
\hline Systolic blood pressure $(\mathrm{mmHg})$ & $128(15)$ & $139(14)$ & $146(21)$ & $153(18)$ \\
\hline Fasting glucose (mmol/l) & $5.4(0.5)$ & $5.8(0.6)$ & $5.4(0.5)$ & $5.9(0.6)$ \\
\hline Total cholesterol (mmol/1) & $6.0(1.1)$ & $6.1(1.1)$ & $6.3(1.1)$ & $6.5(1.2)$ \\
\hline HDL-cholesterol (mmol/l) & $1.3(0.3)$ & $1.0(0.2)$ & $1.4(0.3)$ & $1.0(0.2)$ \\
\hline Triglycerides (mmol/l) & $1.3(0.6)$ & $2.4(1.2)$ & $1.4(0.6)$ & $2.5(1.3)$ \\
\hline
\end{tabular}


Table 3 Hazards ratios (95\% confidence intervals) of the 118 fatal cardiovascular events in 2790 non-diabetic men aged 50-69 year, according to the estimated cardiovascular risk from the SCORE project equation and absence/presence of the NCEP-ATP III metabolic syndrome. The DECODE Study.

CVD risk over 10 years from the SCORE project equation

\begin{tabular}{cccc}
\multicolumn{2}{c}{$<5 \%$} & \multicolumn{3}{c}{$\geq 5 \%$} \\
\hline no syndrome & with syndrome & no syndrome & with syndrome \\
20 deaths, & 13 deaths, & 57 deaths, & 28 deaths, \\
1110 men & 306 men & 941 men & 433 men \\
\hline
\end{tabular}

No adjustments

$$
1 \quad 2.36(1.17-4.74) \quad 3.44(2.06-5.73) \quad 3.52(1.98-6.27)
$$

Adjusting for centre

$$
1 \quad 2.44(1.21-4.91) \quad 3.65(2.16-6.16) \quad 3.97(2.20-7.17)
$$

Adjusting for centre, age

$$
1 \quad 2.47(1.22-4.99) \quad 2.17(1.20-3.93) \quad 2.50(1.31-4.74)
$$

Adjusting for centre, age and the estimated 10-year CVD risk

$$
1 \quad \mathbf{2 . 4 2}(\mathbf{1 . 2 0 - 4 . 8 8}) \quad 1.70(0.91-3.17) \quad 1.87(0.95-3.68)
$$

Dividing men according to CVD risk group

No adjustments

$$
1 \quad \mathbf{2 . 3 7 ( 1 . 1 7 - 4 . 7 6 )} \quad 1 \quad 1.02(0.65-1.62)
$$

Adjusting for centre
1
$2.52(1.24-5.09)$
1
$1.10(0.69-1.74)$

Adjusting for centre and age
1
$2.71(1.33-5.51)$
1
$1.13(0.71-1.80)$

Adjusting for centre, age and the estimated 10-year CVD risk
1
$2.26(1.09-4.68)$
1
$1.08(0.68-1.72)$ 
Table 4 Hazards ratios of the 118 fatal cardiovascular events in 2790 non-diabetic men aged 50-69 years, according to the estimated cardiovascular risk from the SCORE project equation and the NCEP-ATPIII defined abnormalities. Adjustment has been made for age and study centre. The DECODE Study.

\begin{tabular}{|c|c|c|c|c|}
\hline \multirow{3}{*}{ WAIST } & \multicolumn{4}{|c|}{ CVD risk over 10 years from the SCORE project equation } \\
\hline & \multicolumn{2}{|c|}{$<5 \%$} & \multicolumn{2}{|c|}{$\geq 5 \%$} \\
\hline & $\mathrm{WC}<102 \mathrm{~cm}$ & $\mathrm{WC} \geq 102 \mathrm{~cm}$ & $\mathrm{WC}<102 \mathrm{~cm}$ & $\mathrm{WC} \geq 102 \mathrm{~cm}$ \\
\hline & $\begin{array}{l}23 \text { deaths, } \\
1174 \text { men }\end{array}$ & $\begin{array}{l}10 \text { deaths, } \\
242 \text { men }\end{array}$ & $\begin{array}{l}67 \text { deaths, } \\
1060 \text { men }\end{array}$ & $\begin{array}{l}18 \text { deaths, } \\
314 \text { men }\end{array}$ \\
\hline & 1 & $2.24(1.05-4.76)$ & 1 & $0.93(0.54-1.58)$ \\
\hline BLOOD & SBP/DBP & SBP/DBP & SBP/DBP & SBP/DBP \\
\hline \multirow[t]{3}{*}{ PRESSURE } & $<130 / 85$ & $\geq 130 / 85$ & $<130 / 85$ & $\geq 130 / 85$ \\
\hline & $\begin{array}{l}9 \text { deaths, } \\
576 \text { men }\end{array}$ & $\begin{array}{c}24 \text { deaths, } \\
840 \text { men }\end{array}$ & $\begin{array}{l}8 \text { deaths, } \\
192 \text { men }\end{array}$ & $\begin{array}{l}77 \text { deaths, } \\
1182 \text { men }\end{array}$ \\
\hline & 1 & $2.67(1.21-5.88)$ & 1 & $1.82(0.86-3.83)$ \\
\hline \multirow[t]{3}{*}{ GLUCOSE } & $\begin{array}{c}\text { Glucose } \\
<6.1 \mathrm{mmol} / 1\end{array}$ & $\begin{array}{c}\text { Glucose } \\
\geq 6.1 \mathrm{mmol} / 1\end{array}$ & $\begin{array}{l}\text { Glucose } \\
<6.1 \mathrm{mmol} / 1\end{array}$ & $\begin{aligned} & \text { Glucose } \\
\geq & 6.1 \mathrm{mmol} / 1\end{aligned}$ \\
\hline & $\begin{array}{l}25 \text { deaths, } \\
1195 \text { men }\end{array}$ & $\begin{array}{l}8 \text { deaths, } \\
221 \text { men }\end{array}$ & $\begin{array}{l}62 \text { deaths, } \\
1056 \text { men }\end{array}$ & $\begin{array}{l}23 \text { deaths, } \\
318 \text { men }\end{array}$ \\
\hline & 1 & $1.73(0.76-3.91)$ & 1 & $1.05(0.99-1.11)$ \\
\hline \multirow[t]{3}{*}{$\begin{array}{c}\text { HDL- } \\
\text { CHOLESTEROL } \\
\end{array}$} & $\begin{array}{c}\text { HDL-C } \\
\geq 1.04 \mathrm{mmol} / 1\end{array}$ & $\begin{array}{c}\text { HDL-C } \\
<1.04 \mathrm{mmol} / 1\end{array}$ & $\begin{array}{c}\text { HDL-C } \\
\geq 1.04 \mathrm{mmol} / 1\end{array}$ & $\begin{array}{c}\text { HDL-C } \\
<1.04 \mathrm{mmol} / 1\end{array}$ \\
\hline & $\begin{array}{c}15 \text { deaths, } \\
997 \text { men } \\
\end{array}$ & $\begin{array}{c}18 \text { deaths, } \\
419 \text { men }\end{array}$ & $\begin{array}{l}59 \text { deaths, } \\
1020 \text { men }\end{array}$ & $\begin{array}{l}26 \text { deaths, } \\
354 \text { men }\end{array}$ \\
\hline & 1 & $2.72(1.35-5.45)$ & 1 & $1.30(0.81-2.09)$ \\
\hline \multirow[t]{3}{*}{ TRIGLYCERIDE } & $\begin{array}{c}\text { TRIG } \\
<1.70 \mathrm{mmol} / 1\end{array}$ & $\begin{array}{c}\text { TRIG } \\
\geq 1.70 \mathrm{mmol} / 1\end{array}$ & $\begin{array}{c}\text { TRIG } \\
<1.70 \mathrm{mmol} / 1\end{array}$ & $\begin{array}{c}\text { TRIG } \\
\geq 1.70 \mathrm{mmol} / 1\end{array}$ \\
\hline & $\begin{array}{l}21 \text { deaths, } \\
940 \text { men }\end{array}$ & $\begin{array}{l}12 \text { deaths, } \\
476 \text { men }\end{array}$ & $\begin{array}{l}53 \text { deaths, } \\
824 \text { men }\end{array}$ & $\begin{array}{l}32 \text { deaths, } \\
550 \text { men }\end{array}$ \\
\hline & 1 & $1.29(0.63-2.65)$ & 1 & $0.96(0.61-1.50)$ \\
\hline \multirow[t]{3}{*}{$\begin{array}{c}\text { BLOOD } \\
\text { PRESSURE } \\
\text { \& WAIST }\end{array}$} & $\begin{array}{c}\mathrm{SBP} / \mathrm{DBP} \\
<130 / 85 \\
\& / \mathrm{or} \\
\mathrm{WC}<102 \mathrm{~cm} \\
\end{array}$ & $\begin{array}{c}\mathrm{SBP} / \mathrm{DBP} \\
\geq 130 / 85 \\
\& \\
\mathrm{WC} \geq 102 \mathrm{~cm}\end{array}$ & $\begin{array}{c}\mathrm{SBP} / \mathrm{DBP} \\
<130 / 85 \\
\& / \mathrm{or} \\
\mathrm{WC}<102 \mathrm{~cm}\end{array}$ & $\begin{array}{c}\mathrm{SBP} / \mathrm{DBP} \\
\geq 130 / 85 \\
\& \\
\mathrm{WC} \geq 102 \mathrm{~cm}\end{array}$ \\
\hline & $\begin{array}{l}23 \text { deaths, } \\
1229 \text { men }\end{array}$ & $\begin{array}{l}10 \text { deaths, } \\
187 \text { men }\end{array}$ & $\begin{array}{l}68 \text { deaths, } \\
1077 \text { men }\end{array}$ & $\begin{array}{l}17 \text { deaths, } \\
297 \text { men }\end{array}$ \\
\hline & 1 & $3.54(1.65-7.59)$ & 1 & $0.93(0.54-1.59)$ \\
\hline \multirow[t]{3}{*}{$\begin{array}{c}\text { TRIGLYCERIDE } \\
\text { \& WAIST }\end{array}$} & $\begin{array}{c}\text { TRIG } \\
<1.7 \mathrm{mmol} / 1 \\
\& / \mathrm{or} \\
\mathrm{WC}<102 \mathrm{~cm}\end{array}$ & $\begin{array}{c}\text { TRIG } \\
\geq 1.7 \mathrm{mmol} / 1 \\
\& \\
\mathrm{WC} \geq 102 \mathrm{~cm}\end{array}$ & $\begin{array}{c}\text { TRIG } \\
<1.7 \mathrm{mmol} / 1 \\
\& / \mathrm{or} \\
\mathrm{WC}<102 \mathrm{~cm}\end{array}$ & $\begin{array}{c}\text { TRIG } \\
\geq 1.7 \mathrm{mmol} / 1 \\
\& \\
\mathrm{WC} \geq 102 \mathrm{~cm}\end{array}$ \\
\hline & $\begin{array}{l}29 \text { deaths, } \\
1299 \text { men }\end{array}$ & $\begin{array}{l}4 \text { deaths, } \\
117 \text { men }\end{array}$ & $\begin{array}{l}78 \text { deaths, } \\
1205 \text { men }\end{array}$ & $\begin{array}{l}7 \text { deaths, } \\
169 \text { men }\end{array}$ \\
\hline & 1 & $1.91(0.66-5.54)$ & 1 & $0.69(0.31-1.51)$ \\
\hline
\end{tabular}




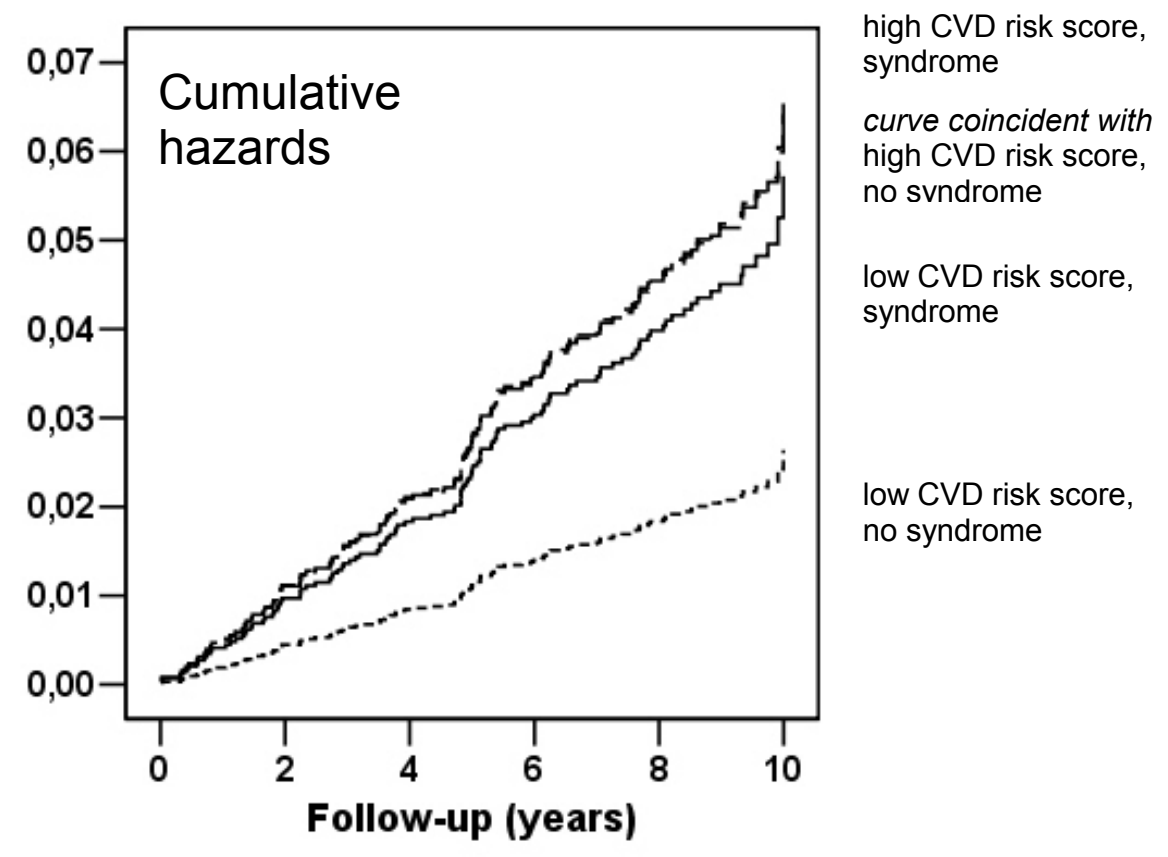

